\title{
Moulding the Millennial Maze
}

\author{
${ }^{1}$ Prof. Anant Deogaonkar, ${ }^{2}$ Mr. Prashant Deshpande, ${ }^{3}$ Ms. Sampada Nanoty \\ ${ }^{1}$ Assistant Professor, Department of Management Technology, Shri Ramdeobaba College of Engineering \& \\ Management, Nagpur \\ ${ }^{2}$ Head HR, Mahindra \& Mahindra Ltd \\ ${ }^{3}$ M.S. University, Vadodara \\ Email:deogaonkara1@rknec.edu,DESHPANDE.PRASHANT@mahindra.com,sampadananoty@gmail.com
}

\section{Received: $20^{\text {th }}$ September 2018, Accepted: $11^{\text {th }}$ October 2018, Published: $31^{\text {st }}$ October 2018}

\begin{abstract}
The current era of millennials caters the vibrant range of the young workforce, instilled with creative versatility. Today's youth propels the management setup to evolve a new groove by shifting from the top-down managerial pyramid to collaborative inspiration. The leaders and developers today need to set their eyes on the creative efficiencies of the emerging workforce and groom them in its appropriate accordance. Millennials demand for sovereignty in their workstyle rather than enforcement. So it is important to create and adopt anew management techniques for the congruous development and effective efficiency utilisation of $21^{\text {st }}$ century millennials. Therefore, the sole aim here is the need to devise suitable management structure for the potential utility of the millennials as the young willing workforce.
\end{abstract}

\section{Keywords}

Millennia, Management Structure, Collaborative Inspiration

\section{Introduction}

Today's synchronous era is bestowed upon with prodigious young workforce. Back in 2015 itself the millennials, i.e. the population aged between 19-32 approximately had surpassed the number of those of X generation composed of the age range estimated 35-50, being the largest demographic workforce. This wide range of millennial workforce on the field strongly impacts the right from the substructure to the nub of the workplace. Perhaps, it is hard to analyse and showcase the entire impact and the shifts naturally effectuated by millennials. This brings the idea of leading millennials rather than managing them. The regular set management system works on the principle of exploiting people's skills for increasing efficiency and ultimately benefitting the business. Millennial workforce suits itself better with a leadership approach which highlights on motivating and developing people for the benefit of the team. The top-down managerial approach has surely created successful teams in the past times, but the age of millennials feeds on mentorship, professional development, coopetition and respect.

\section{Guiding the Millennials (Mentorship)}

Millennials strategize to grow in their position by flourishing new ideas by proposing their ideals to respective managers. They work practicing the daily basis reviews and guidance from their managers instead of waiting for the yearly review. Comfortable working with the team, knowing their struggling fellow millennial and rendering the needed help guidance. Moreover, the guidance and mentorship isn't merely imperative for the development of skills, but it even positively affects the millennial team's retention. Let us screen result of a survey:

Deloitte Millennial survey, 2016: Younger professionals intending to stay with their organisation for more than five years are twice as likely to have a mentor/guide than not $(68 \%-32 \%$, respectively). Hence, millennials desiderate guidance, and if they fail to find it at their present working place they rather prefer to move to another that would supply them advise.

\section{Focusing on the Training and Professional Development}

Millennials are keenly and deeply interrogative and introspective regarding their careers (approximately $87 \%$ of the majority according to Gallup report). So though they are keen to seek on job training but expect it to be diverse and not of one-size-fits-all kind. This workforce being idealistic believes in smart-time information from Google and YouTube rather than spending hours at seminars, being unattached but connected, nor do they merely seek guidance from the experts but they take up quick discussions with their peers and colleagues and prefer to learn from them. Millennial developmental traits can be easily understood with that of cloud-based Learning Management System, which allows employers to create and deliver course content on demand. This system allows employees the accessibility of required guidance at any moment and on any device with the flexibility of time and location. 


\section{Deriving Careers Paths}

The millennials are very well updated with the scenario of their near past portraying their boomer parents and other former generation acquaintances getting let go from the organisations they had been dutiful and conscientious for years long, the reason being lack of skill up gradation, and not being familiar to market standard requirements, having performed only a particular task for years.

Millennials take charge of their career paths and readily will to take the decisions at the sharp edges, such as exploring for the positions at another company to expose their versatile potential. Gallup reports that about $93 \%$ millennials have left an employer in order to change roles. This clearly exhibits their trait of being unattached with the jobs or brands they work with unlike the past generation. Moreover, these fraternities of millennial is connected with all the sources of information and acquire an easy access to it, being self dependant. Hence, for retaining millennials it's not enough to manage their current roles but rather to act as a leader furnishing to develop the team's skills in such a way that is homogeneous to their career ambits and also establishing the respective organisation's talent pipeline.

\section{Connecting Work to a Great Purpose}

The generation of millennials is ambitious and passionate regarding their work, so they more likely turn up to perform purposeful work unlike the past generation. Not merely money, but the thought of realisation that their specific work makes a difference, leads a paragon keeps their working spirit motivated. The managers ought to make the millennials understand that why particular work is assigned to them and how it complements with overall company's mission.

Dwight D. Eisenhower said, "Leadership is the art of getting someone else to do something you want to be done because he wants to do it." When leading millennials one has to abide by the explanation of the work transparency and not by mere assignment and enforcement of work.

\section{Creative Collaboration Leads Millennials}

The formal top-down managerial approach does not rightly fit the millennial workforce in it. Millennial fraternity would fit right in a circular set up which involves multitask and binds equally well with the loops on both of it's sides. A team of millennials working in a circular set up, will develop superb connectivity, lead to easy access, eliminate the enforcement requirement, will improve on the authority and accountability terms, lessen the strain of the tough delegation task and moreover will add to the development of not just the workforce but most importantly escalate the goodwill of the company in every term. The managers should note that while leading millennials they ought to be a part of the circular chain and not it's owner. Managers have to keep the lines of communication open when leading millennials and ought to adopt a healthy give and take approach as the managers may receive several surprise learnings from the millennial workforce. Hence, creative collaborations will bring out the best ideals individually, as a group and will also fetch out the best out from the organisation.

Certain reports find that millennials struggle to find good jobs that engage them. Millennials have the highest rates of unemployment and underemployment in the U.S., and only $29 \%$ of employed millennials are engaged at work. Half of millennials say they feel good about the amount of money they have to spend, and less than $40 \%$ are what can be defined as "thriving" in any one aspect of well-being. Millennials have not been able to forge better paths for themselves than many Americans have before them. While the dream of all parents is to have their children lead a better life than their own, not all millennials are positioned for such success.

\section{Conclusion}

Will millennials be really able to get what they want from their work and life? Yes, the leading strategy and the circular creative collaborations instead of the top-down pyramid will fulfil both the purposes; one of the work satisfaction of the millennials and the second of the fruitful working and positive growth of an organisation abiding by its mission. Leaders are broadly turning their attention to the millennial generation whose attitude and preferences may profoundly reshape the workplaces and even the society.

\section{References}

1]https://hbr.org/2016/06/do-managers-and-leaders-really-do-differentthings?utm_campaign=elearningindustry.com\&utm_source=\%2Fleading-millennials-vs-managing-differencematters\&utm_medium=linkThe 2016 Deloitte Millennial Survey Winning over the next generation of leaders 2]https://www2.deloitte.com/content/dam/Deloitte/global/Documents/About-Deloitte/gx-millenial-survey-2016exec-summary.pdf?utm_campaign $=$ elearningindustry.com\&utm_source $=\% 2$ Fleading-millennials-vs-managing- 
difference-matters\&utm_medium $=$ link 3]https://www.gallup.com/workplace/236477/millennials-work-

ife.aspx?utm_campaign=elearningindustry.com\&utm_source $=\% 2$ Fleading-millennials-vs-managing-differencematters\&utm_medium $=$ link 4]https://www.gallup.com/workplace/236471/millennial-job-hoppersseek.aspx?utm_campaign=elearningindustry.com\&utm_source=\%2Fleading-millennials-vs-managing-differencematters\&utm_medium $=$ link 